\title{
Post-mortem Interval Effects on the Phosphorylation of Signaling Proteins
}

\author{
Jianlin Li', Todd D Gould², Peixiong Yuan ${ }^{1,2}$, Husseini K Manji² and Guang Chen*,2 \\ 'Laboratory of Molecular Pathophysiology, Wayne State University School of Medicine, Detroit, MI, USA; '2 Laboratory of Molecular \\ Pathophysiology, National Institute of Mental Health, Bethesda, MD, USA
}

\begin{abstract}
Post-mortem brain tissue provides a unique opportunity to uncover the genes or proteins involved in the pathophysiology of neuropsychiatric disorders. Protein phosphorylation is a common protein modification within intracellular signaling pathways that affects the distribution and function of protein, and has been hypothesized to be of major importance in both the pathophysiology and treatment of major neuropsychiatric disorders. Thus, we were interested in ascertaining the stability of the phosphorylated forms of proteins that are involved in cellular signaling. Antibodies against phospho-tyrosine, phospho-threonine, and phospho-PKA substrates were used to examine the PMI effects on the general amounts of proteins in their phosphorylated form. Phospho-specific antibodies for ERK, JNK, RSK, CREB, and ATF-2 were used to test the effects of PMI on specific proteins whose functioning are known to be regulated markedly by phosphorylation. We found that PMI rapidly decreased the levels of proteins in their phosphorylated states and also decreased the total levels of certain proteins. The PMl effects were observed in the samples stored at both $4^{\circ} \mathrm{C}$ and room temperature, in both frontal cortex and hippocampus. Thus, it appears that measurements (such as two-dimensional gel electrophoresis and functional assays) that rely on the phosphorylation state of proteins would be extremely sensitive to PMI.

Neuropsychopharmacology (2003) 28, I0 I7-1025, advance online publication, 12 March 2003; doi: I 0.1038/sj.npp. I 3001 I2
\end{abstract}

Keywords: Alzheimer's disease; bipolar disorder; depression; schizophrenia; two-dimensional gel electrophoresis; protein phosphorylation

\section{INTRODUCTION}

Post-mortem brain tissue is increasingly being utilized to study the molecular and cellular pathophysiology of neuropsychiatric disorders. Analysis of post-mortem brains has proven invaluable in helping to uncover the neuropathology of numerous diseases, including Alzheimer's, Huntington's, and Parkinson's disease; indeed, these studies have facilitated the elucidation of the central pathophysiology of these illnesses (Greenfield et al, 1997). While these diseases show anatomical changes that are identifiable by gross post-mortem brain examination, there may exist more subtle cellular and molecular changes in the brains of patients with other neuropsychiatric disorders, including bipolar disorder, unipolar depression, and schizophrenia (Gould and Manji, 2002; Harrison, 1996, 1999, 2002; Knable and Webster, 2001; Rajkowska, 2002; Vawter et al, 2000). Thus, post-mortem brain specimens represent an invaluable

\footnotetext{
*Correspondence: Dr G Chen, Laboratory of Molecular Pathophysiology, Bldg 49, Room BIEEI6, Mood \& Anxiety Disorders Program, NIMH, NIH, Bethesda, MD 20892, USA, Tel: +I 3014518425 , Fax: + I 30 I 480 0I23, E-mail: cheng@intra.nimh,nih.gov

Received 16 July 2002; revised 5 November 2002; accepted 12 November 2002

Online publication: 15 November 2002 at http: //www.acnp.org/ citations/Npp | | | 50243 |
}

resource to investigate the pathophysiology of these, and numerous other, neuropsychiatric illnesses.

There are many confounding factors that effect the outcome of post-mortem measurements including the post-mortem interval (PMI), cerebral hemisphere selected, method of sampling and storing tissue, anatomical precision during dissection, histological processing technique, age, gender, general health preceding death (agonal state, which is generally related to brain $\mathrm{pH}$ ), neurological and psychiatric state, medication, time of day of death (circadian state), and date of death (seasonal state) (Lewis, 2002; Perry and Perry, 1983; Ravid et al, 1992).

The PMI is the period from death to freezing of brain specimens for long-term storage at $-80^{\circ} \mathrm{C}$ (Harrison and Kleinman, 2000), and may be one of the more important variables (Dodd et al, 1988). Most protocols and brain banks that supply post-mortem brains for analysis attempt to keep the PMI as short, and as uniform, as possible. Unfortunately, given the difficulty in collecting postmortem brain samples, it is often impossible to avoid long and often variable PMIs. The problem with PMIs may be more pronounced in the study of illnesses like bipolar disorder, depression, and schizophrenia, in which individuals generally die 'unexpectedly', and outside of a wellmonitored long-term care facility, thus resulting in a relatively long PMI. Furthermore, it is often difficult to 
ascertain exactly when expiration occurred, leading to inaccuracies in PMI estimates.

The phosphorylation of cellular signaling proteins has been implicated in the pathophysiology of numerous neuropsychiatric diseases (Gould et al, 2002; Jope, 1999; Konradi and Heckers, 2001; Lenox and Hahn, 2000; Maccioni et al, 2001). Indeed, the phosphorylated form of a protein is clearly of major biological interest; it often affects the function and/or subcellular distribution of enzymes, receptors, neurotransmitter transporters, ion channels, and transcription factors. Thus, the ability to measure phosphorylated proteins in their native state could facilitate post-mortem investigations of neuropsychiatric disorders. Phosphorylation also effects the migration of proteins during two-dimensional gel electrophoresis (Sickmann and Meyer, 2001), a technique that may be useful for analyzing disease-specific changes in post-mortem brain specimens (Edgar et al, 1999; Fountoulakis et al, 2001; Johnston-Wilson et al, 2000). For these reasons, we investigated the effects of PMI on protein phosphorylation state in mouse brain tissue, where we can control exactly the PMI and are assured minimal genetic/tissue heterogeneity by utilizing inbred strains. We chose proteins based upon their putative involvement in the pathophsyiology and treatment of mood disorders (Gould et al, 2002), and their specificity for different phospho-amino acids (see Materials and methods section). We found that PMI produced profound and relatively rapid effects on the phosphorylation of proteins involved in intracellular signaling.

\section{MATERIALS AND METHODS}

Male C57/BL6 mice 6-7 weeks of age from Harlan ( 20 g) were housed $4-5$ per cage in a $12 \mathrm{~h}$ light/dark cycle with free access to water and food. All mice were killed by decapitation between 9 and $10 \mathrm{am}$. Heads of animals were covered or placed in a small plastic bag, and stored at either room temperature or at $4^{\circ} \mathrm{C}$. Frontal cortex and hippocampus were dissected on ice immediately, 4, 8, 14, $24,36,48 \mathrm{~h}$ (or 8,24 , and 48 for the room temperature storage) following decapitation. Immediately after dissection, brain specimens were rapidly frozen in dry ice and stored at $-80^{\circ} \mathrm{C}$ until further analyses. The frontal cortex and hippocampus samples were homogenized by sonication in a protein extraction buffer containing $20 \mathrm{mM}$ Tris- $\mathrm{HCl}$ (pH 7.5), $150 \mathrm{mM} \mathrm{NaCl}, 1 \mathrm{mM}$ EDTA, $1 \mathrm{mM}$ EGTA, $1 \%$ Triton X-100, $2.5 \mathrm{mM}$ sodium pyrophosphate, $1 \mathrm{mM} \beta$-glycerophosphate, protease inhibitor cocktail
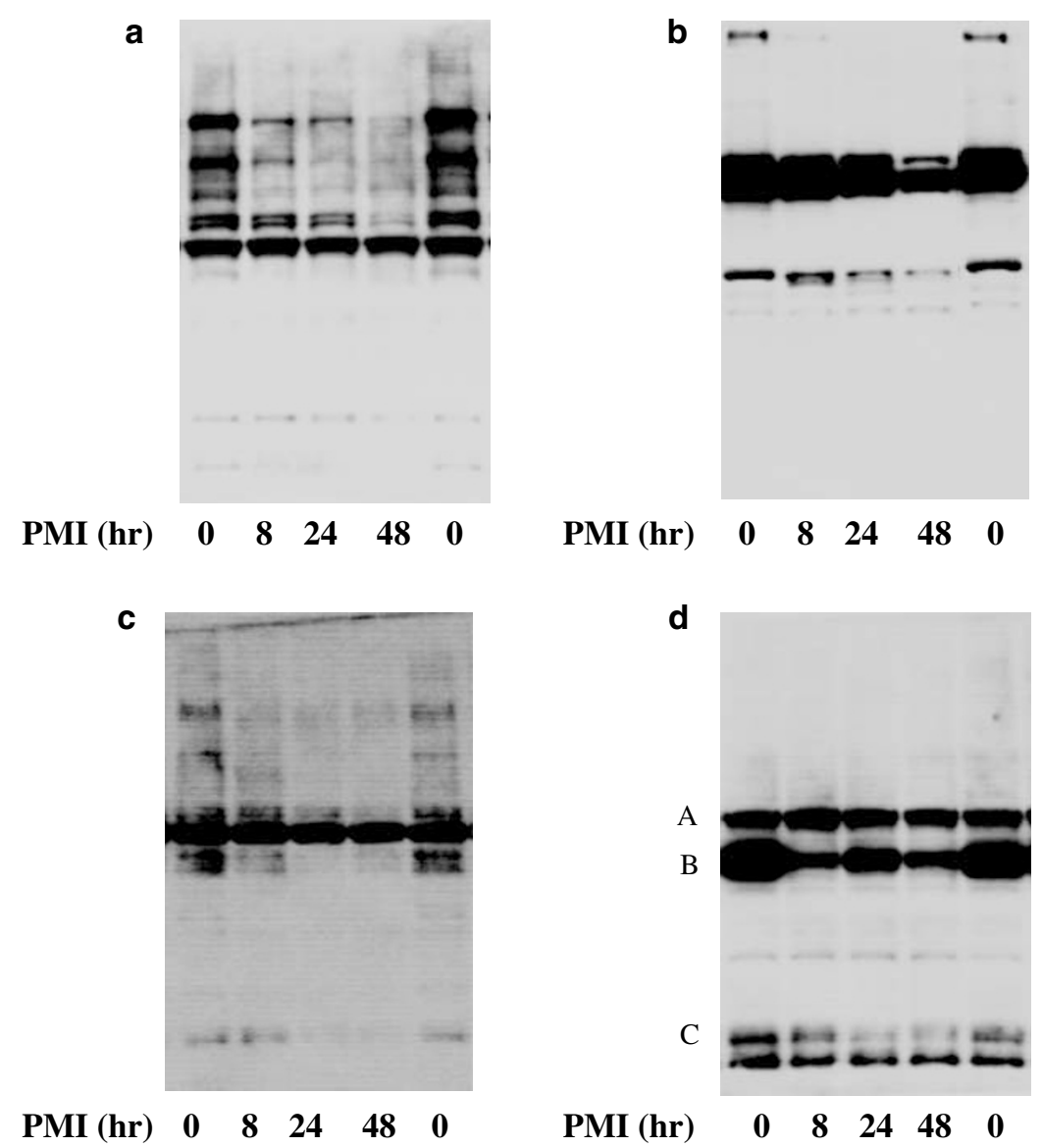

Figure I PMI decreases phosphoprotein levels in the mouse frontal cortex. $40 \mu \mathrm{g}$ of protein was loaded on I0\% gel and the immunoblot was stained with an antibody that recognizes (a) phospho-tyrosine, (b) phospho-threonine, (c) phospho-PKA substrate, and (d) acetylated lysine in a fashion largely independent of the surrounding amino-acid sequence. Similar results are also obtained from two additional groups of mice. Similar results were obtained from mouse hippocampus samples. The acetylated lysine antibody identifies three primary bands (d). Among these number bands, an increasing PMI reduced levels of band $\mathrm{C}$, and altered the levels of band $\mathrm{B}$ in a tri-phasic manner. 
(SIGMA), and phosphatase inhibitor cocktail I and II (SIGMA). The homogenates were then centrifuged at $14000 \mathrm{~g}$ for $10 \mathrm{~s}$ to remove undissolved debris. Protein concentrations were determined using the Bio-Rad protein assay kit (Bradford, 1976). The linearity of the protein concentration for immunoblotting for each protein was ascertained by resolution of selected concentrations of protein.

Subsequent protein immunoblotting was performed using previously described methods (Yuan et al, 2001). In brief, samples were subjected to SDS-PAGE. The amount of protein loaded was $40 \mu \mathrm{g}$ per lane, except for p-ERK, ERK, Bcl-2, and Bcl-x, for which $10 \mu \mathrm{g}$ was loaded. Proteins thus resolved were then electrophoretically transferred to nitrocellulose membranes. Nonspecific binding on the nitrocellulose was blocked with $5 \%$ nonfat dry milk/TBST, and then incubated with a primary antibody. Primary antibodies were either from Cell Signaling Technology (p-PKA substrate (catalog 9621), p-tyrosine (9411), p-threonine (9381), acetylated lysine (9681), p-CREB (9191; site Ser 133), CREB (9192), p-ATF2 (9221; Thr 71),
ATF2 (9222), ERK1/2 (9102), JNK1/2 (9252), c-Jun (9162)) or Santa Cruz Biotechnology, Inc. (p-ERK1/2 (SC7383; Tyr 204), p-JNK1/2 (SC-6254; Thr 183/Tyr 185), Bcl-2 (SC-492)). The antibodies for immunoblots were diluted either 1:1000 (for Cell Signaling Technology) or 1:200 (Santa Cruz Biotechnology, Inc.). After blotting with secondary antibody (anti-rabbit IgG, Cell Signaling Technology, 1:2000; anti-mouse IgG, Amersham Biosciences, 1:3000), the immunocomplex was detected with an ECL or ECL plus kit (Amersham Biosciences). Quantitation of the immunoblots was performed by densitometric scanning of the film using an Image Analysis System (with NIH 1.55). An aliquot of pooled 'standard' appropriate rat brain was run on one lane of each gel. Data were normalized against the 'standard' to minimize between blot variability. Statistical analysis was performed by analysis of variance, followed by Fisher's PLSD. $P<0.05$ was considered significant. Data are expressed as the means \pm SE. Reported statistical significance is between $0 \mathrm{~h}$ PMI and the PMI of interest.

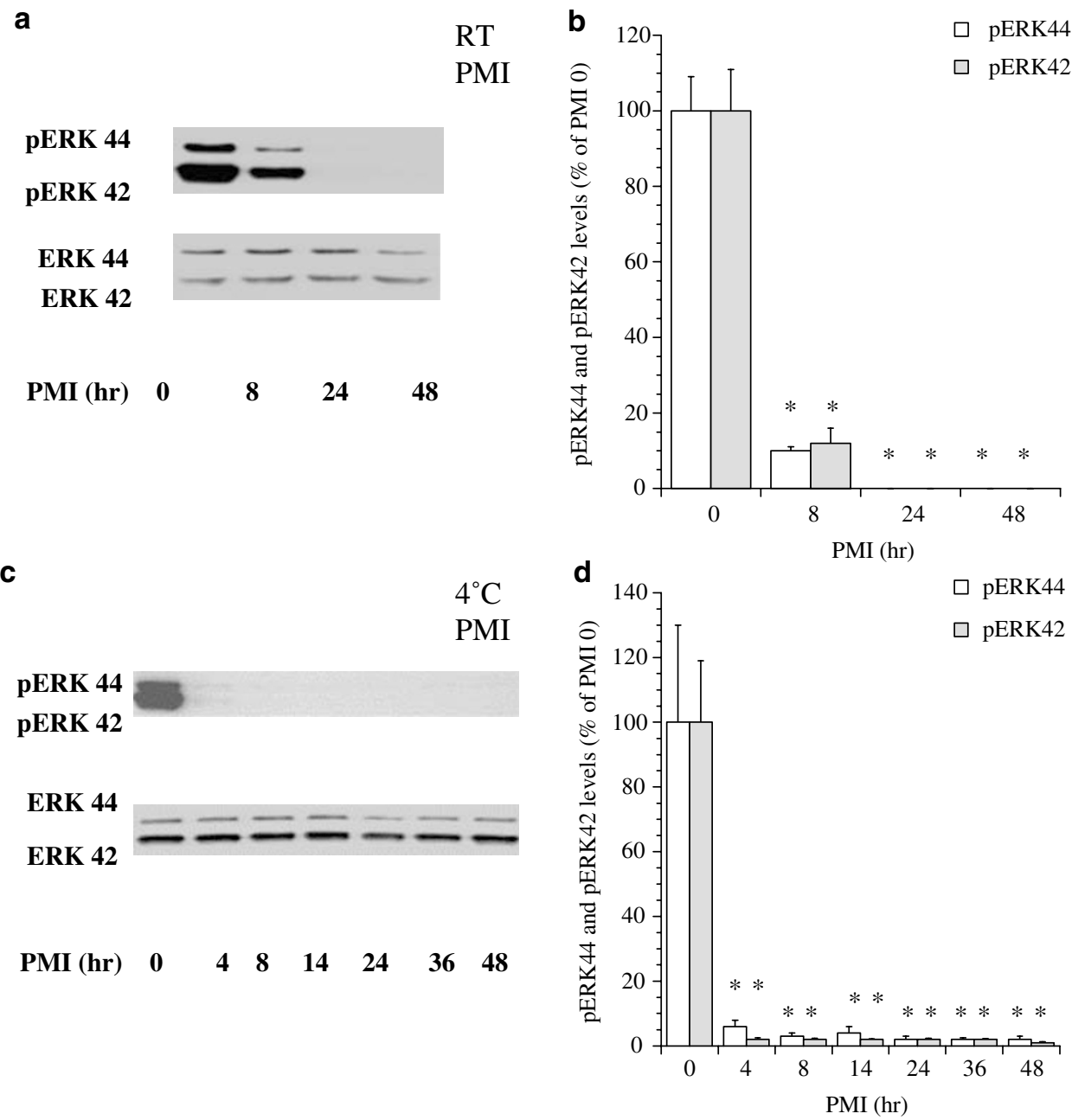

Figure 2 PMI decreases the phosphorylated forms of ERK ( 42 and $44 \mathrm{kDa}$ ), but does not change the total protein levels. During the PMI, brains were stored at either room temperature $(\mathrm{a}, \mathrm{b})$ or $4^{\circ} \mathrm{C}(\mathrm{c}, \mathrm{d})$. The graph represents the mean densitometry reading $\pm \mathrm{SE}$ from a total of three $(\mathrm{RT})$ or four $\left(4^{\circ} \mathrm{C}\right)$ mice $\left(* P<0.05\right.$ Fisher's PLSD). $P$-ERK $44 R T\left(F_{3,8}=112 ; P<0.000 I\right), 4^{\circ} \mathrm{C}\left(F_{6,21}=10.6 ; P<0.000 I\right) ; p-E R K 42 R T\left(F_{3,8}=66.1 ; P<0.000 I\right), 4^{\circ} \mathrm{C}\left(F_{6,21}=27.2 ;\right.$ $P<0.000 I)$ 


\section{RESULTS}

Mice were sacrificed, and stored at room temperature in 0,8 , 24 , or $48 \mathrm{~h}$ prior to dessection. We initially examined the effects of PMI on total phosphorylated proteins using antibodies specific for the phosphorylation of specific amino acids, but not specific for individual proteins or the surrounding amino-acid sequence. Antibodies specific for phospho-tyrosine and phospho-threonine containing proteins revealed that PMI reduced the phosphorylation of the majority of these substrates (Figure 1a,b). Similar results were obtained using an antibody for the phosphorylated forms of potential phospho-protein kinase A (PKA) substrates (Figure 1c). We were additionally interested if PMI had an effect on other post-translational modifications. To test this, we used an antibody specific for acetylated-lysine containing proteins. Among a limited number of primary bands, the PMI reduced levels of band $\mathrm{C}$, and altered the levels of band B in a tri-phasic manner (Figure 1d).
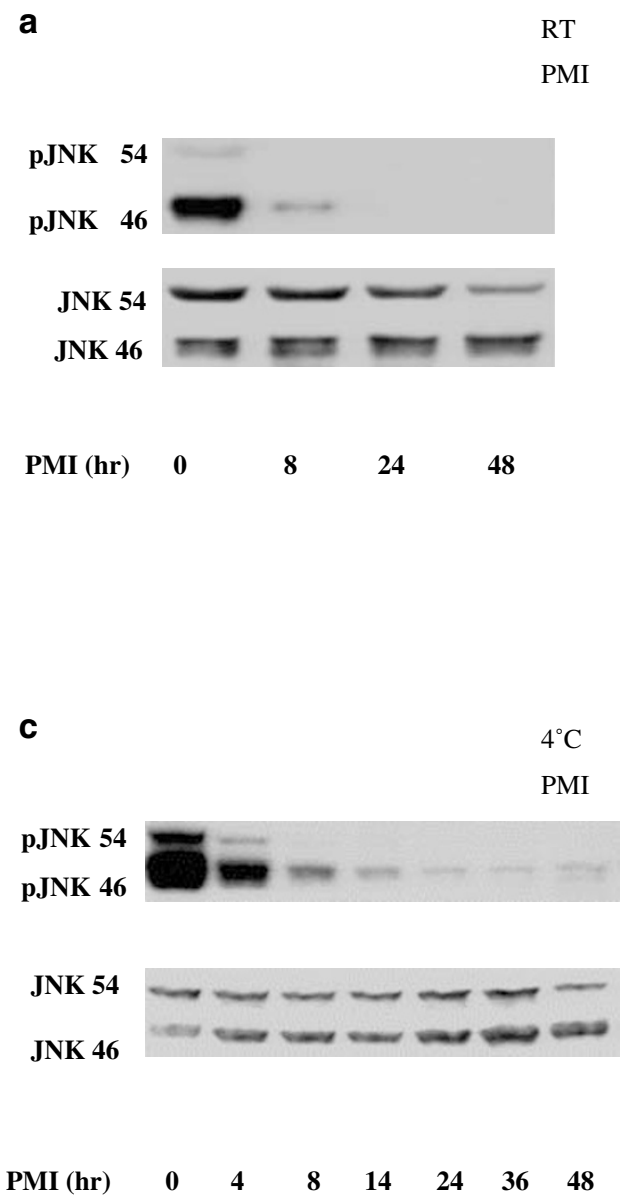
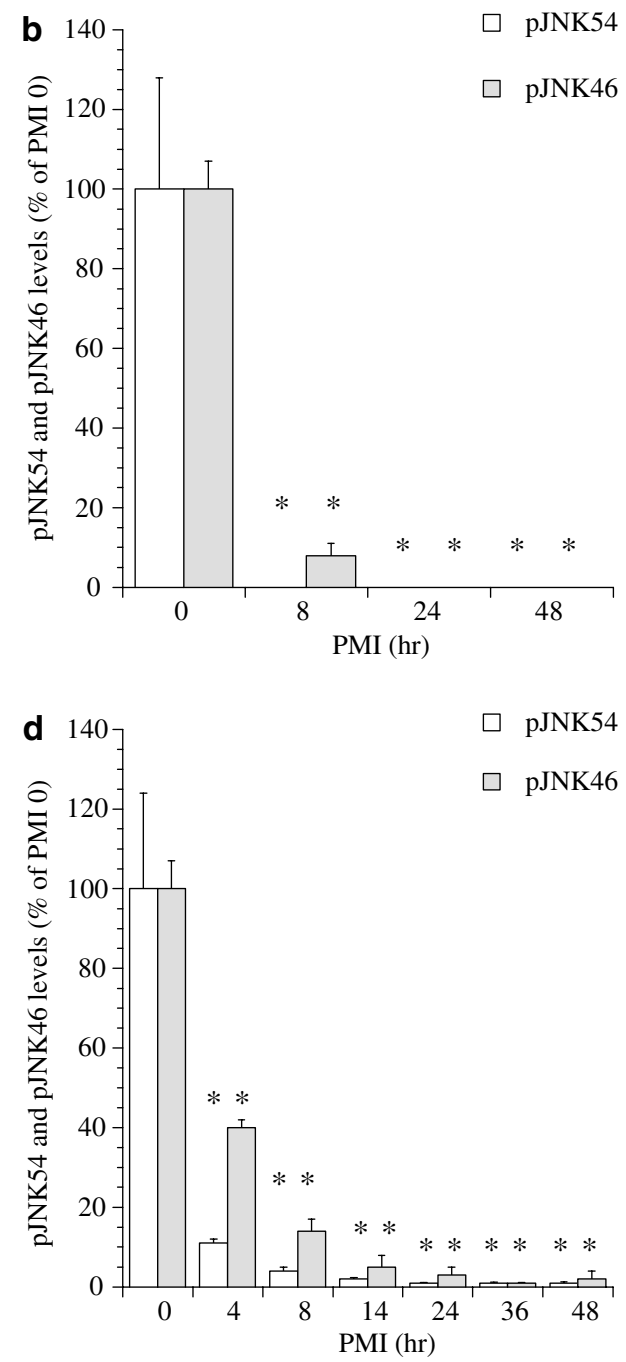

Figure $3 \mathrm{PMI}$ decreases the phosphorylated forms of JNK (46 and $54 \mathrm{kDa}$ ), but does not change the total protein levels. During the PMI, brains were stored at either room temperature $(\mathrm{A}, \mathrm{B})$ or $4^{\circ} \mathrm{C}(\mathrm{C}, \mathrm{d})$. The graph represents the mean densitometry reading $\pm \mathrm{SE}$ from a total of three $(\mathrm{RT})$ or four $\left(4^{\circ} \mathrm{C}\right)$ mice $\left(* P<0.05\right.$ Fisher's PLSD). $\mathrm{P}-J \mathrm{NK} 54 \mathrm{RT}\left(\mathrm{F}_{3,8}=12.5 ; P=0.0022\right), 4^{\circ} \mathrm{C}\left(\mathrm{F}_{6,21}=15.9 ; P<0.000 \mathrm{I}\right) ; \mathrm{p}-\mathrm{JNK} 46 \mathrm{RT}\left(\mathrm{F}_{3,8}=\mid 55 ; P<0.000 \mathrm{I}\right), 4^{\circ} \mathrm{C}\left(\mathrm{F}_{6,21}=\mid 27\right.$; $P<0.000 I)$. 


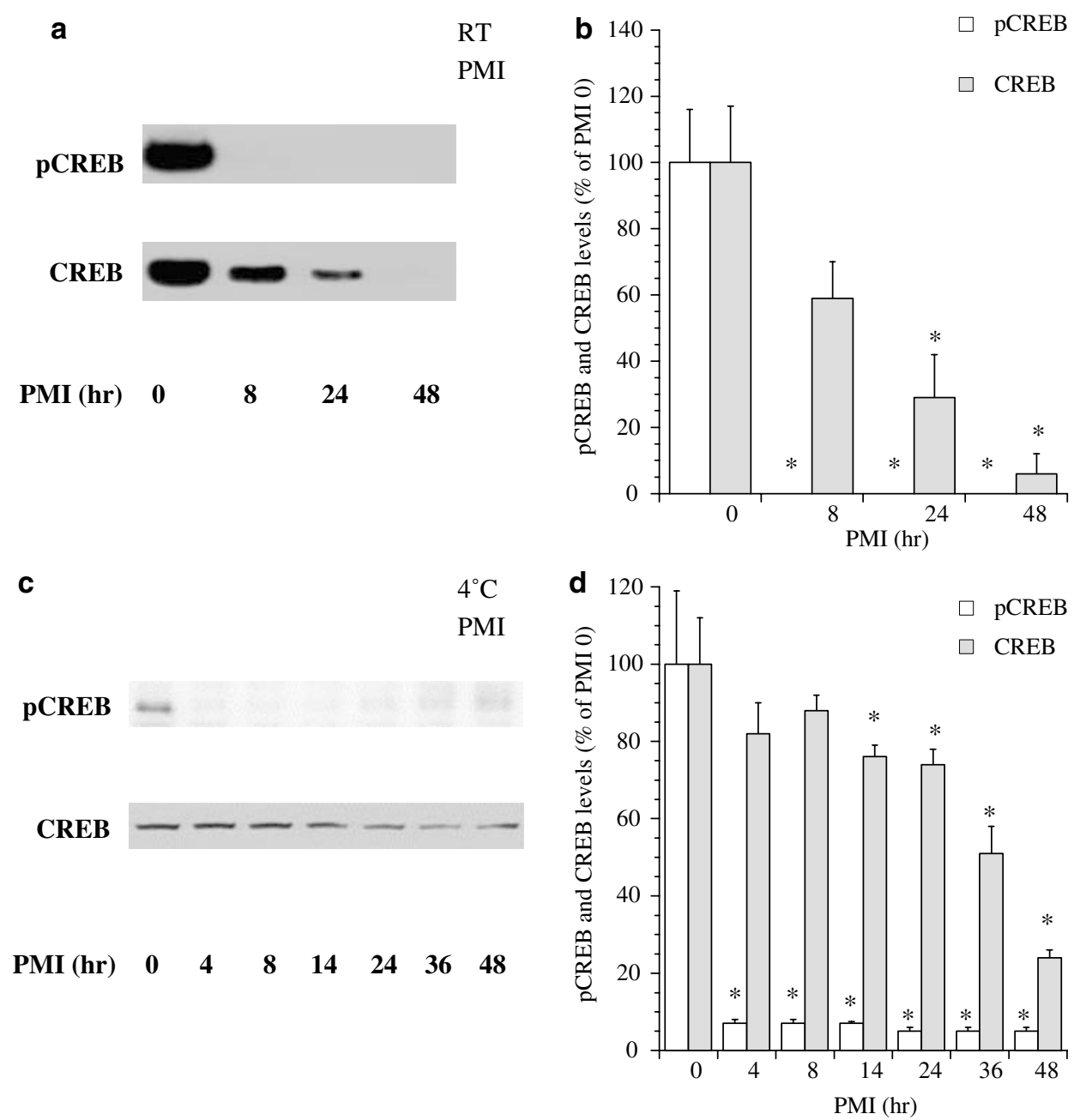

Figure 4 PMI decreases the phosphorylated form of CREB. PMI also decreases the total protein levels of CREB ( $43 \mathrm{kDa}$ ). During the PMI, brains were stored at either room temperature $(\mathrm{a}, \mathrm{b})$ or $4^{\circ} \mathrm{C}(\mathrm{c}, \mathrm{d})$. The graph represents the mean densitometry reading $\pm \mathrm{SE}$ from a total of three $(\mathrm{RT})$ or four $\left(4^{\circ} \mathrm{C}\right)$ mice ( ${ }^{*} P<0.05$ Fisher's PLSD). $p$-CREB RT $\left(F_{3,8}=39.1 ; P<0.000 I\right), 4^{\circ} \mathrm{C}\left(F_{6,21}=23.9 ; P<0.000 I\right)$; total-CREB RT $\left(F_{3,8}=10.5 ; P=0.0038\right), 4^{\circ} \mathrm{C}\left(F_{6,21}=15.5\right.$; $P<0.0001)$.

significantly changed using our methods. All experiments were repeated with samples from the hippocampus, with findings similar to those shown in Figures 2-6 (data not shown).

Since the PMI often encompasses time in refrigeration, we repeated the experiments; however, the brains were placed immediately at $4^{\circ} \mathrm{C}$ after mice were sacrificed, and additional time points were used $(0,4,8,14,24,36$, and $48 \mathrm{~h}$ ). In general, results at $4^{\circ} \mathrm{C}$ were similar to those obtained at room temperature. The earliest PMI $(4 \mathrm{~h})$ had a dramatic effect on the levels of all phosphorylated proteins (Figures 2-5, panels c and d). Consistent with the results obtained when brains were stored at room temperature, there was variability on the effect of PMI on the total levels of proteins analyzed (Figures 2-6, panels $c$ and d). PMI decreased the levels of many proteins, but other protein levels were unchanged. The proteins that decreased in immunolabeling - or remained stable-after storage at room temperature were similar to those that were stored at $4^{\circ} \mathrm{C}$. For example, PMI had an effect on the protein levels of C-Jun (Figure 6) and CREB (Figure 4), but had no significant effect on Bcl-2 (Figure 6) or ERK (42 or 44;
Figure 2). All experiments were repeated with samples from the hippocampus, with findings similar to those shown in Figures 2-6 (data not shown).

\section{DISCUSSION}

PMI has a major impact on the levels of proteins in the phosphorylated (often functional) state as detected by immunoblot (Figures 1-5). Furthermore, PMI decreased the total level of some proteins (Figures 2-6). Storage of brains at $4^{\circ} \mathrm{C}$ did not appear to affect the decrease in phospho-protein levels; however, it did appear to delay the degradation of some total proteins (Figures 2-6). Phosphorylation of the tau protein has been investigated in a number of studies; these studies have shown that while phosphorylation of most sites on tau are highly unstable during the PMI, some appear not to be affected to the same degree (Burack and Halpain, 1996; Gartner et al, 1998; Matsuo et al, 1994; Song et al, 1997). Our data are generally consistent with - and extends - this series of findings, suggesting that it may be difficult to measure the level of most phosphoproteins that are involved in intracellular 


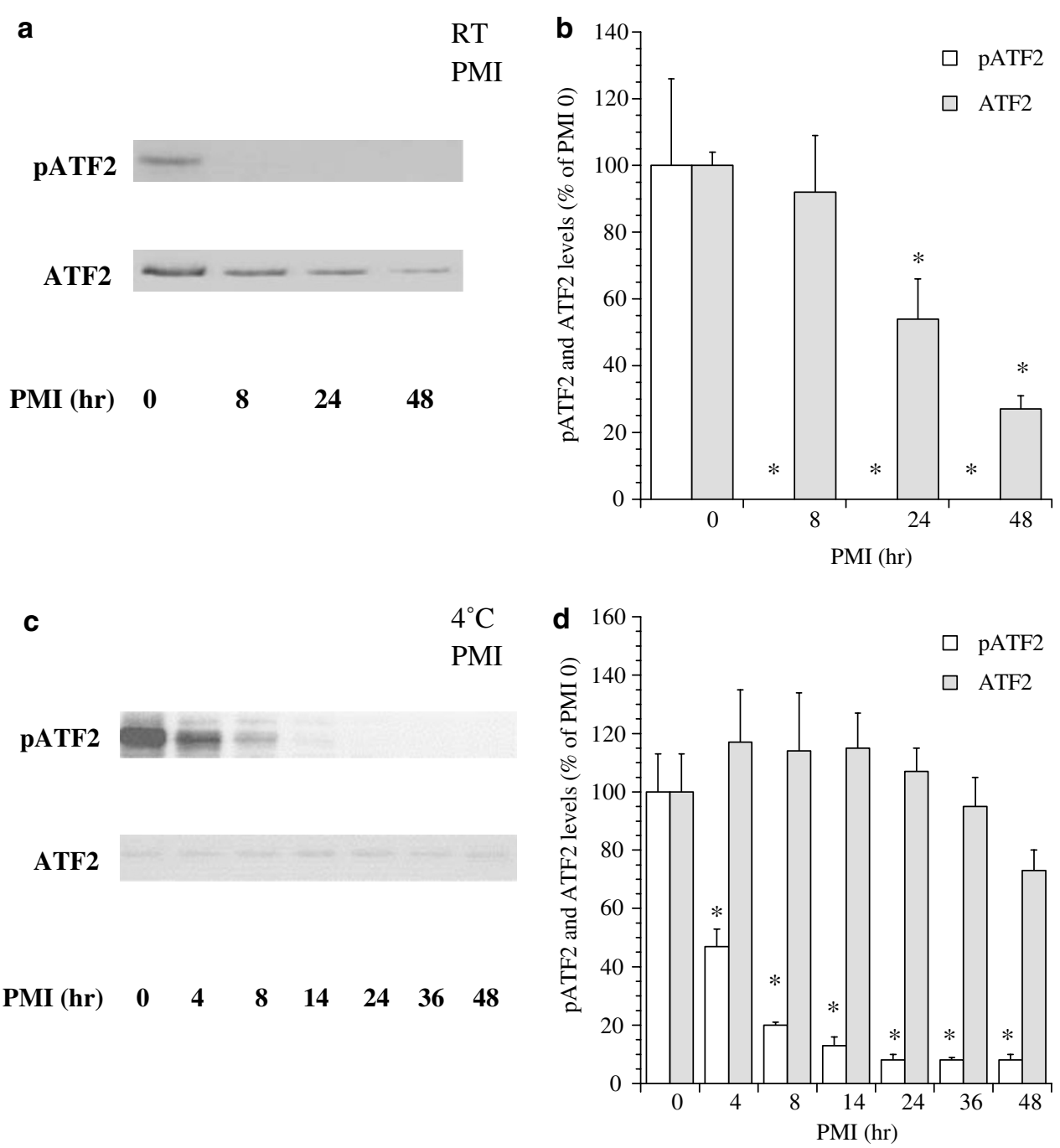

Figure $5 \mathrm{PMI}$ decreases the phosphorylated form of ATF2 $(65 \mathrm{kDa})$. PMI also decreases the total protein levels of ATF2 during storage at room temperature $(\mathrm{a}, \mathrm{b})$. However, total protein levels do not change significantly when brains are stored at $4^{\circ} \mathrm{C}(\mathrm{c}, \mathrm{d})$. The graph represents the mean densitometry reading $+\mathrm{SE}$ from a total of three $(\mathrm{RT})$ or four $\left(4^{\circ} \mathrm{C}\right)$ mice $(* P<0.05$ Fisher's $P L S D)$. p-ATF2 $R T\left(F_{3.8}=15.0 ; P=0.0012\right), 4^{\circ} \mathrm{C}\left(F_{6.21}=37.6\right.$; $P<0.000$ I $)$; total-ATF2 RT $\left(F_{3,8}=9.52 ; P=0.005 \mathrm{I}\right), 4^{\circ} \mathrm{C}\left(F_{6,21}=1.35 ; P=0.28\right)$.

signaling in post-mortem human brain specimens (where the average PMI is often longer than $24 \mathrm{~h}$ ). However, considering that nonprotein-specific phospho-antibodies appeared to identify some phosphorylated proteins unaffected by PMI (Figure 1), it is possible that not all phosphorylated proteins are affected to such a degree (Walaas et al, 1989). Furthermore, as many enzymes are regulated by phosphorylation, it may be difficult to measure reliably the in vitro activity (as a correlate of in vivo activity) of many enzymes from the post-mortem brain. Indeed, numerous studies have found that the activities of certain enzymes are sensitive to PMI (Bowen et al, 1976; Puymirat et al, 1979; Roytta et al, 1980; Spokes and Koch, 1978); our data suggest a possible mechanism underlying these findings.

Clearly, as witnessed by the relative stability of the total level of some proteins compared to others among our data, there is considerable variability of the PMI stability of total protein levels. This finding is consistent with previous studies addressing the stability of other biological products such as protein levels (Akil and Lewis, 1994; Fountoulakis et al, 2001; Geddes et al, 1995; Li et al, 1996; Schwab et al, 1994), mRNA (Burke et al, 1991; Finger et al, 1987; Pardue et al, 1994; Schramm et al, 1999), ligand binding (Kornhuber et al, 1988), monoamine levels (Spokes and Koch, 1978), and enzyme activity (Bowen et al, 1976; Puymirat et al, 1979; Roytta et al, 1980; Spokes and Koch, 1978) in brain specimens; while findings for a specific measure are generally reproducible among studies, there is variability among members of the same class (ie different mRNAs, enzymes, etc). Thus, it cannot be assumed that because one particular protein, mRNA, etc is stable, all are stable during a certain PMI. In addition to PMI and storage temperature, other factors such as agonal state at death (Bowen et al, 1976; Butterworth et al, 1983; Harrison et al, 1991; Lewis and Akil, 1997; Perry et al, 1977a, 1982; Spokes, 1979; Yates et al, 1990), pH (generally related to agonal state) (Barton et al, 1993; Eastwood and Harrison, 2000; Harrison et al, 1995; Johnston et al, 1997; Kingsbury et al, 1995), freezing time (Roytta et al, 1980), and time or season of death (Bucht et al, 1981; Carlsson et al, 1980; Perry et al, 


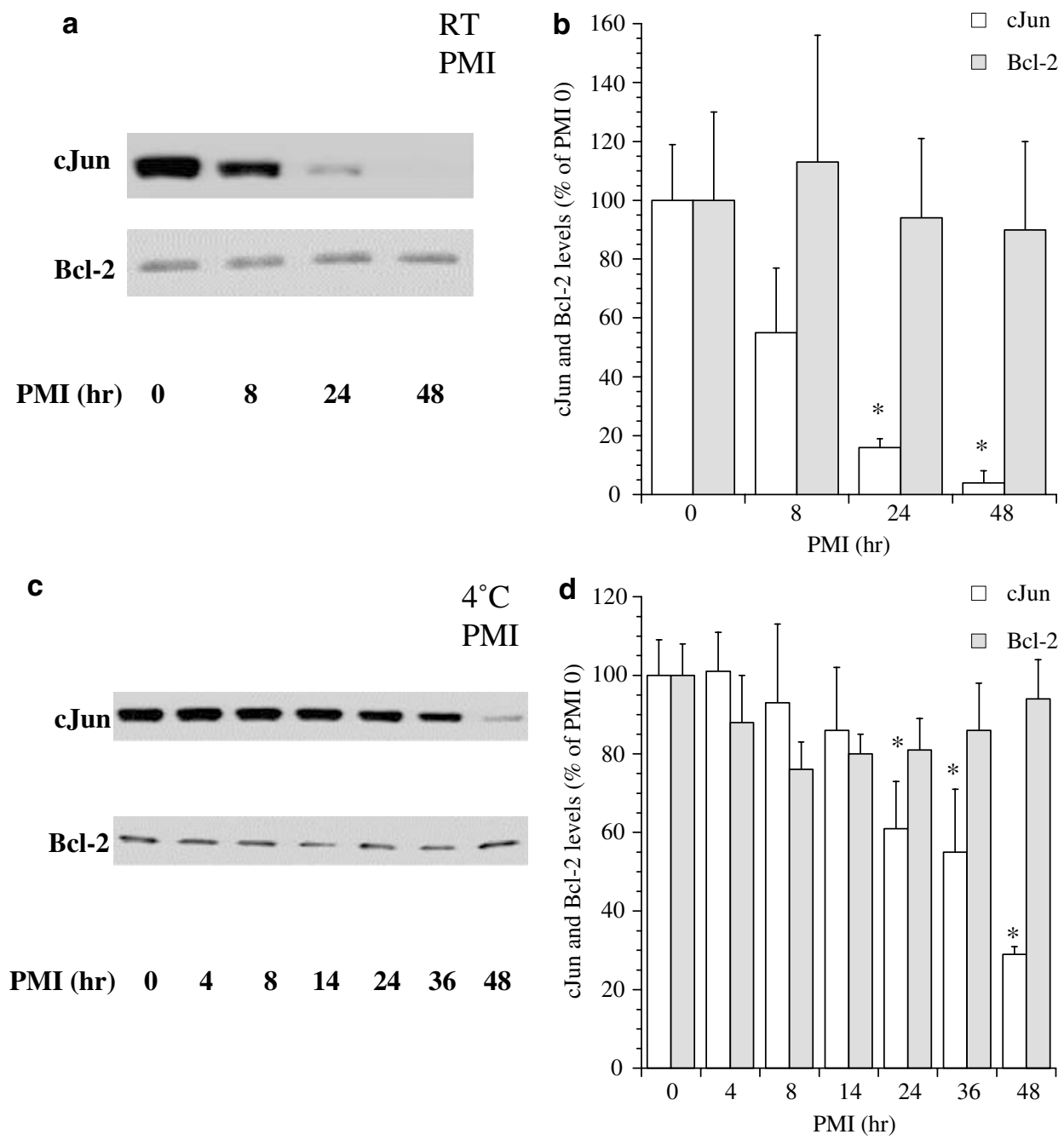

Figure 6 PMI decreases the total level of c-Jun $(39 \mathrm{kDa})$, but does not significantly change the total level of Bcl-2 (26 kDa). During the PMl, brains were stored at either room temperature $(\mathrm{a}, \mathrm{b})$ or $4^{\circ} \mathrm{C}(\mathrm{c}, \mathrm{d})$. The graph represents the mean densitometry reading $\pm \mathrm{SE}$ from a total of three $(\mathrm{RT})$ or four $\left(4^{\circ} \mathrm{C}\right)$ mice $\left(* P<0.05\right.$ Fisher's PLSD). c-Jun $R T\left(F_{3,8}=8.95 ; P=0.0062\right), 4^{\circ} \mathrm{C}\left(F_{6,21}=4.38 ; P=0.005 \mathrm{I}\right) ; \mathrm{Bcl}-2 \mathrm{RT}\left(F_{3,8}=0.099 ; P=0.96\right), 4^{\circ} \mathrm{C}\left(F_{6,21}=0.853 ;\right.$ $P=0.544)$.

1977a-d), among many others, have been found to influence the degradation - or level — of biological products in postmortem brain specimens. Thus, it remains critical to ascertain the post-mortem stability, and the stability under other conditions, of the biological product.

While important, post hoc correlational analysis may not always be indicative of the stability of proteins. There is likely a greater relative variation in post-mortem human specimens - as opposed to animal models - because of the factors discussed in this manuscript, and/or the relative genetic and environmental heterogeneity found in humans. Furthermore, as has recently been articulated, it is quite possible that the biological measure had already changed substantially from the in vivo value and that within the PMI of post-mortem brain specimens $(12-48 \mathrm{~h})$ there is little variation (Lewis, 2002). As previously suggested (Lewis, 2002; Lewis and Akil, 1997; Perry and Perry, 1983; Spokes and Koch, 1978), it may be advisable to test - in experimental animal models - the stability of the specific biological products of interest during various PMIs and under different post-mortem conditions prior to perform- ing a similar analysis in human post-mortem brain specimens. Importantly, it must be kept in mind that there exists the possibility that protein and protein phosphorylation in the human brain may not degrade at the same rate or at the same manner as in the mouse brain. A valuable resource may be the availability of human post-mortem brain tissue with experimentally defined post-mortem storage time$\mathrm{s}$ - and other post-mortem factors - from the same individual (to limit human heterogeneity). The availability of such a repository would allow for more scientifically rigorous testing of the effects of posmortem factors than is currently available when utilizing post hoc correlational analyses.

Clearly, the human post-mortem brain represents a tremendously important resource for the study of neuropsychiatric disorders (Duman, 2002). However, care must be taken to ascertain the effect of PMI on protein levels, or post-translational forms of proteins under investigation. While PMIs generally found in most studies may be adequate to quantitate the total levels of many proteins, extreme caution is likely required in the interpretation of 
phosphoprotein levels, two-dimensional gel electrophoresis, and the activity of enzymes regulated by phosphorylation.

\section{ACKNOWLEDGMENTS}

Our research is supported by the Intramural Research Program of the National Institute of Mental Heath, the Stanley Medical Research Institute, and the National Alliance for Research on Schizophrenia and Depression (NARSAD).

\section{REFERENCES}

Akil M, Lewis DA (1994). The distribution of tyrosine hydroxylaseimmunoreactive fibers in the human entorhinal cortex. $\mathrm{Neu}$ roscience 60: 857-874.

Barton AJ, Pearson RC, Najlerahim A, Harrison PJ (1993). Pre- and postmortem influences on brain RNA. J Neurochem 61: 1-11.

Bowen DM, Smith CB, White P, Davison AN (1976). Neurotransmitter-related enzymes and indices of hypoxia in senile dementia and other abiotrophies. Brain 99: 459-496.

Bradford MM (1976). A rapid and sensitive method for the quantitation of microgram quantities of protein utilizing the principle of protein-dye binding. Anal Biochem 72: 248-254.

Bucht G, Adolfsson R, Gottfries CG, Roos BE, Winblad B (1981). Distribution of 5-hydroxytryptamine and 5-hydroxyindoleacetic acid in human brain in relation to age, drug influence, agonal status and circadian variation. J Neural Transm 51: 185-203.

Burack MA, Halpain S (1996). Site-specific regulation of Alzheimer-like tau phosphorylation in living neurons. Neuroscience 72: 167-184.

Burke WJ, O'Malley KL, Chung HD, Harmon SK, Miller JP Berg L (1991). Effect of pre- and postmortem variables on specific mRNA levels in human brain. Brain Res Mol Brain Res 11: $37-41$.

Butterworth J, Yates CM, Simpson J (1983). Phosphate-activated glutaminase in relation to Huntington's disease and agonal state. J Neurochem 41: 440-447.

Carlsson A, Svennerholm L, Winblad B (1980). Seasonal and circadian monoamine variations in human brains examined post mortem. Acta Psychiatr Scand 280(Suppl): 75-85.

Dodd PR, Hambley JW, Cowburn RF, Hardy JA (1988). A comparison of methodologies for the study of functional transmitter neurochemistry in human brain. J Neurochem $\mathbf{5 0}$ 1333-1345.

Duman RS (2002). Windows on the human brain and the neurobiology of psychiatric illness. Neuropsychopharmacology 26: 141-142.

Eastwood SL, Harrison PJ (2000). Hippocampal synaptic pathology in schizophrenia, bipolar disorder and major depression: a study of complexin mRNAs. Mol Psychiatry 5: 425-432.

Edgar PF, Schonberger SJ, Dean B, Faull RL, Kydd R, Cooper GJ (1999). A comparative proteome analysis of hippocampal tissue from schizophrenic and Alzheimer's disease individuals. Mol Psychiatry 4: 173-178.

Finger JM, Mercer JF, Cotton RG, Danks DM (1987). Stability of protein and mRNA in human postmortem liver-analysis by two-dimensional gel electrophoresis. Clin Chim Acta 170: 209218.

Fountoulakis M, Hardmeier R, Hoger H, Lubec G (2001). Postmortem changes in the level of brain proteins. Exp Neurol 167: 86-94.

Gartner U, Janke C, Holzer M, Vanmechelen E, Arendt T (1998). Postmortem changes in the phosphorylation state of tau-protein in the rat brain. Neurobiol Aging 19: 535-543.
Geddes JW, Bondada V, Tekirian TL, Pang Z, Siman RG (1995). Perikaryal accumulation and proteolysis of neurofilament proteins in the post-mortem rat brain. Neurobiol Aging 16: 651-660.

Gould TD, Chen G, Manji HK (2002). Mood stabilizer psychopharmacology. Clin Neurosci Res 2: 193-212.

Gould TD, Manji HK (2002). Signaling networks in the pathophysiology and treatment of mood disorders. J Psychosom Res 53: 687-697.

Greenfield JG, Graham DI, Lantos PL (1997). Greenfield's Neuropathology. Arnold: New York.

Harrison PJ (1996). Advances in post mortem molecular neurochemistry and neuropathology: examples from schizophrenia research. Br Med Bull 52: 527-538.

Harrison PJ (1999). The neuropathology of schizophrenia. A critical review of the data and their interpretation. Brain 122: 593-624.

Harrison PJ (2002). The neuropathology of primary mood disorder. Brain 125: 1428-1449.

Harrison PJ, Heath PR, Eastwood SL, Burnet PW, McDonald B, Pearson RC (1995). The relative importance of premortem acidosis and postmortem interval for human brain gene expression studies: selective mRNA vulnerability and comparison with their encoded proteins. Neurosci Lett 200: 151-154.

Harrison PJ, Kleinman JE (2000). Methodological issues. In: Harrison PJ, Roberts GW (eds). The Neuropathology of Schizophrenia. Oxford University Press: New York. pp 339-350.

Harrison PJ, Procter AW, Barton AJ, Lowe SL, Najlerahim A, Bertolucci PH et al (1991). Terminal coma affects messenger RNA detection in post mortem human temporal cortex. Brain Res Mol Brain Res 9: 161-164.

Johnston NL, Cervenak J, Shore AD, Torrey EF, Yolken RH, Cerevnak J (1997). Multivariate analysis of RNA levels from postmortem human brains as measured by three different methods of RT-PCR. J Neurosci Methods 77: 83-92.

Johnston-Wilson NL, Sims CD, Hofmann JP, Anderson L, Shore $\mathrm{AD}$, Torrey EF et al (2000). Disease-specific alterations in frontal cortex brain proteins in schizophrenia, bipolar disorder, and major depressive .disorder The Stanley Neuropathology Consortium. Mol Psychiatry 5: 142-149.

Jope RS (1999). Anti-bipolar therapy: mechanism of action of lithium. Mol Psychiatry 4: 117-128.

Kingsbury AE, Foster OJ, Nisbet AP, Cairns N, Bray L, Eve DJ et al (1995). Tissue $\mathrm{pH}$ as an indicator of mRNA preservation in human post-mortem brain. Brain Res Mol Brain Res 28: 311-318. Knable MB, Webster MJ (2001). Foreword. Brain Res Bull 55: 567568.

Konradi C, Heckers S (2001). Antipsychotic drugs and neuroplasticity: insights into the treatment and neurobiology of schizophrenia. Biol Psychiatry 50: 729-742.

Kornhuber J, Retz W, Riederer P, Heinsen H, Fritze J (1988). Effect of antemortem and postmortem factors on [3H]glutamate binding in the human brain. Neurosci Lett 93: 312-317.

Lenox RH, Hahn CG (2000). Overview of the mechanism of action of lithium in the brain: fifty-year update. J Clin Psychiatry 61(Suppl 9): 5-15.

Lewis DA (2002). The human brain revisited. Neuropsychopharmacology 26: 143-154.

Lewis DA, Akil M (1997). Cortical dopamine in schizophrenia: strategies for postmortem studies. J Psychiatr Res 31: 175-195.

Li X, Greenwood AF, Powers R, Jope RS (1996). Effects of postmortem interval, age, and Alzheimer's disease on G-proteins in human brain. Neurobiol Aging 17: 115-122.

Maccioni RB, Munoz JP, Barbeito L (2001). The molecular bases of Alzheimer's disease and other neurodegenerative disorders. Arch Med Res 32: 367-381.

Matsuo ES, Shin RW, Billingsley ML, Van deVoorde A, O'Connor M, Trojanowski JQ et al (1994). Biopsy-derived adult human 
brain tau is phosphorylated at many of the same sites as Alzheimer's disease paired helical filament tau. Neuron 13: 9891002 .

Pardue S, Zimmerman AL, Morrison-Bogorad M (1994). Selective postmortem degradation of inducible heat shock protein 70 (hsp70) mRNAs in rat brain. Cell Mol Neurobiol 14: 341-357.

Perry EK, Gibson PH, Blessed G, Perry RH, Tomlinson BE (1977a). Neurotransmitter enzyme abnormalities in senile dementia. Choline acetyltransferase and glutamic acid decarboxylase activities in necropsy brain tissue. J Neurol Sci 34: 247-265.

Perry EK, Perry RH (1983). Human brain neurochemistry-some postmortem problems. Life Sci 33: 1733-1743.

Perry EK, Perry RH, Taylor MJ, Tomlinson BE (1977b). Circadian variation in human brain enzymes. Lancet 1: 753-754.

Perry EK, Perry RH, Taylor MJ, Tomlinson BE (1977c). Evidence of a circadian fluctuation in neurotransmitter enzyme activities measured in autopsy human brain. J Neurochem 29: 593-594.

Perry EK, Perry RH, Tomlinson BE (1977d). Circadian variations in cholinergic enzymes and muscarinic receptor binding in human cerebral cortex. Neurosci Lett 4: 185-189.

Perry EK, Perry RH, Tomlinson BE (1982). The influence of agonal status on some neurochemical activities of postmortem human brain tissue. Neurosci Lett 29: 303-307.

Puymirat J, Javoy-Agid F, Gaspar P, Ploska A, Prochiantz A, Agid $Y$ (1979). Post mortem stability and storage in the cold of brain enzymes. J Neurochem 32: 449-454.

Rajkowska G (2002). Cell pathology in bipolar disorder. Bipolar Disord 4: 129-116.

Ravid R, Van Zwieten EJ, Swaab DF (1992). Brain banking and the human hypothalamus - factors to match for, pitfalls and potentials. Prog Brain Res 93: 83-95.

Roytta M, Laaksonen H, Frey H, Riekkinen P, Rinne UK (1980). Critical evaluation of the postmortem factors influencing neurochemical analyses of brain autopsies. Acta Neurol Scand 61: 88-106.
Schramm M, Falkai P, Tepest R, Schneider-Axmann T, Przkora R, Waha A et al (1999). Stability of RNA transcripts in post-mortem psychiatric brains. J Neural Transm 106: 329-335.

Schwab C, Bondada V, Sparks DL, Cahan LD, Geddes JW (1994). Postmortem changes in the levels and localization of microtubule-associated proteins (tau, MAP2 and MAP1B) in the rat and human hippocampus. Hippocampus 4: 210-225.

Sickmann A, Meyer HE (2001). Phosphoamino acid analysis. Proteomics 1: 200-206.

Song J, Combs CK, Pilcher WH, Song LY, Utal AK, Coleman PD (1997). Low initial tau phosphorylation in human brain biopsy samples. Neurobiol Aging 18: 475-481.

Spokes EG (1979). An analysis of factors influencing measurements of dopamine, noradrenaline, glutamate decarboxylase and choline acetylase in human post-mortem brain tissue. Brain 102: 333-346.

Spokes EG, Koch DJ (1978). Post-mortem stability of dopamine, glutamate decarboxylase and choline acetyltransferase in the mouse brain under conditions simulating the handling of human autopsy material. J Neurochem 31: 381-383.

Vawter MP, Freed WJ, Kleinman JE (2000). Neuropathology of bipolar disorder. Biol Psychiatry 48: 486-504.

Walaas SI, Perdahl-Wallace E, Winblad B, Greengard P (1989). Protein phosphorylation systems in postmortem human brain. $J$ Mol Neurosci 1: 105-116.

Yates CM, Butterworth J, Tennant MC, Gordon A (1990). Enzyme activities in relation to $\mathrm{pH}$ and lactate in postmortem brain in Alzheimer-type and other dementias. J Neurochem 55: 16241630.

Yuan PX, Huang LD, Jiang YM, Gutkind JS, Manji HK, Chen G (2001). The mood stabilizer valproic acid activates mitogenactivated protein kinases and promotes neurite growth. J Biol Chem 276: 31674-31683. 